\title{
Article
}

\section{Mental health care and resistance to fascism}

Mckeown, Mick and Mercer, D.

Available at http://clok.uclan.ac.uk/4127/

Mckeown, Mick ORCID: 0000-0003-0235-1923 and Mercer, D. (2010) Mental health care and resistance to fascism. Journal of Psychiatric and Mental Health Nursing, 17 (2). pp. 152-161. ISSN 13510126

It is advisable to refer to the publisher's version if you intend to cite from the work. http://dx.doi.org/10.1111/j.1365-2850.2009.01489.x

For more information about UCLan's research in this area go to http://www.uclan.ac.uk/researchgroups/ and search for < name of research Group>.

For information about Research generally at UCLan please go to http://www.uclan.ac.uk/research/

All outputs in CLoK are protected by Intellectual Property Rights law, including Copyright law. Copyright, IPR and Moral Rights for the works on this site are retained by the individual authors and/or other copyright owners. Terms and conditions for use of this material are defined in the policies page.

\section{CLoK}

Central Lancashire online Knowledge www.clok.uclan.ac.uk

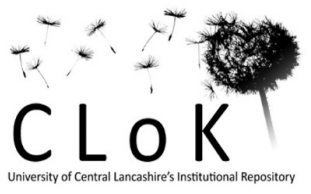


Mick McKeown \& Dave Mercer. Mental Healthcare and Resistance to Fascism . Journal of Psychiatric and Mental Health Nursing

\section{Abstract}

Mental health nurses have a critical stake in resisting the right-wing ideology of British fascism. Particularly concerning is the contemporary effort of the British National Party (BNP) to gain credibility and electoral support by the strategic re-packaging of a racist and divisive political manifesto. Evidence that some public sector workers are affiliated with the BNP has relevance for nursing at a series of levels, not least the incompatibility of party membership with a requirement of the Professional Code to avoid discrimination. Progressive advances, though, need to account for deep rooted institutionalised racism in the discourse and practice of healthcare services. The anomalous treatment of black people within the mental health services, alongside racial abuse experienced by ethnic minority staff, is discussed in relation to the concept of race as a powerful social category and construction. The murder of the mentally ill and learning disabled in Nazi Germany, as an adjunct of racial genocide, is presented as an extreme example where professional ethics was undermined by dominant political ideology. Finally, the complicity of medical and nursing staff in the state sanctioned, bureaucratic, killing that characterised the Holocaust is revisited in the context of ethical repositioning for contemporary practice and praxis.

Key words: mental health, political issues, ethics, ethnicity 


\section{Accessible summary}

- The ideas and politics of British nationalism are highly topical at the moment. Issues of race and racism are key elements of this sort of fascist political movement. There are clear links between modern fascist parties and the wartime Nazis.

- The history of mental health and psychiatric services shows up problems in how ethnic minorities have been treated.

- The Holocaust offers examples of terrible treatment of people with mental health problems, including the active participation of nurses in programmes of sterilisation and murder.

- We can learn lessons from all of this that are relevant to today's nurses and ethical care.

- We conclude that mental health nurses should be a visible part of the resistance to rightwing racist politics.

\section{Introduction}

In this paper we argue that healthcare workers, nurses, and mental health practitioners in particular, have an important stake in resistance to the racist nationalism espoused by the British National Party (BNP). The subject is topical for a number of reasons, not least the current electoral ambitions of British fascism in tandem with a re-emergence of depressed economic circumstances which have historically been exploited by right-wing ideologues. Arguably, racism and the derogatory treatment of other minorities is a particularly germane issue for mental health nurses. Mental health services have had a peculiarly chequered history in dealing with notions of race and other dimensions of human difference. Yet, nursing has also been associated with progressive politics and resistance to racism and other forms of discrimination. Reflections on the relationship between fascism and 
historical abuses of vulnerable groups, including the mentally ill and learning disabled, posit key lessons for nurses and other health practitioners. Examination of current BNP policy, and rhetoric, relevant to mental health and health services suggests important implications for social cohesion, raising stark questions over the professional ethics of practitioners who express affinity for the party or its manifesto. We conclude that mental health nurses and service users should be active in combating the growth of parties like the BNP and join in resistive activity organised by trade unions, communities, and anti-fascist groups.

\section{British nationalism and healthcare}

Despite being in an electoral minority, there has been a notable increase in visibility of right wing nationalist political parties, opposed to liberal democracy, across Europe (Brechon \& Mitra 1992, Luther 2000). Following the demise of the aggressive National Front in the 1980s, British nationalism has reinvented itself under the label of the BNP. Working hard to present itself in a more palatable guise, it continues to target electoral gains amongst disaffected white working class communities (Ware 1996, Husbands 1988). Rattansi (2007: 159) makes a direct parallel between unprecedented levels of electoral support for the BNP, in sections of East London and a number of northern towns, with racially motivated violence and, significantly, institutionalised discrimination:

\footnotetext{
"Teacher racism is not an inconsiderable obstacle, as shown by a number of studies. Social audit studies of hiring practices of private companies, and adding up the costs of compensation payments for racial discrimination by the National Health Service and other agencies also reveal how stubbornly racism can remain embedded in managerial cultures and practices".
}

Latterly, the leaking of the BNP membership list has provoked heated debate over the compatibility of public sector employees belonging to an apparently divisive and discriminatory organisation (Newman 2009). There has been particular interest in the implications for the nursing community (McKeown \& Mercer 2008). The BNP website privileges British citizens in statements about 
healthcare, and blames falling standards of care and hygiene on immigrant labour in the NHS. The Nursing and Midwifery Council Code of Professional Conduct (NMC 2008: 2) states in relation to the requirement to 'Treat People as Individuals':

"You must not discriminate in any way against those in your care".

The NMC website (2009) offers somewhat equivocal advice on the subject of affiliation to the BNP stating that whilst nurses are free to join any legally constituted political party, they must 'demonstrate a personal and professional commitment to equality and diversity'. Arguably, these are mutually exclusive objects. This guidance continues:

\footnotetext{
"The NMC does not forbid anyone on the register from being a member of any lawful political party or organisation. However, your fitness to practise could be called into question if you allow your political views or personal beliefs to contribute to behaviour that was contrary to your Code".
}

It is difficult to conceive of circumstances where personal views and beliefs are completely divorced from behaviour. BNP health policy, evidenced from the national website (BNP 2009), is limited to three short paragraphs, including a commitment to a free NHS, staffing numbers and wages. The BNP leadership often tortuously attempt to explain that they are nationalists not racists, yet an article by Baxter (2009) currently available on their website explicitly, and unapologetically, identifies race as a central theme in their ideology. Perhaps the most telling policy is the implicitly racist: "We will see to it that no money is given in foreign aid while our own hospitals are short of beds and the staff to run them". Unsurprisingly, this rhetoric fails to engage with the facts that large numbers of overseas staff help to keep the NHS running. Anti-fascist campaigns often explicitly highlight the threat posed to public services by nationalistic BNP policies. The trade union Unison, for example, approaching the May 2008 elections, argued that if BNP policies were enacted:

\footnotetext{
"The NHS would collapse because $38 \%$ of all doctors working in hospitals in England qualified outside Britain, $40 \%$ of new dentists were born abroad, $16 \%$ of nurses come from black and Asian backgrounds, while 44,000 overseas nurses worked in the NHS last year alone" (Unison Communications 2008: 1).
} 
In earlier decades, when British nationalism was identified with the National Front, various progressive social movements emerged in resistance, including the Anti-Nazi League and Rock Against Racism. Similar movements were evident in mental health care, notably in groups such as 'Psychologists against the Nazis' (Parker 2001, Psychologists against the Nazis 2001).

\section{Race, racism and discriminatory practices in mental health care}

The notion of race is pivotal in the political rhetoric of the far-right. As such, it is worth exploring the treatment of the concept of race within psychiatric services, noting similarities in institutionalised encounters with other minority groups. The history of black people's and other minorities' engagement with psychiatry is replete with anomalies in diagnosis, care and treatment. The experience of black men in particular has been so profoundly different from similarly situated white counterparts that a plethora of recent policy statements have been forged (see DoH 2005, NIMHE 2003, Keating et al 2002). These mirror a growing societal concern with race and racism, crystallising around the murder of Stephen Lawrence and subsequent inquiry which stressed the notion of institutional racism as a focus for public service reform (MacPherson 1999).

Recognition of racial differences in the mental health system are longstanding, with evidence accumulating in a number of research studies, epidemiological accounts and audits, including the Mental Health Act Commission 'Census' observations (see Bhui et al 2003, Health Care Commission, Mental Health Act Commission \& National Institute for Mental Health England 2007, 2005). Associated with this have been various attempts to theoretically account for identified discrepancies (see Rogers \& Pilgrim 2005, Stowell Smith \& McKeown 2001). In parallel to the experiences of black service users there is also a history of racism targeting black staff. The levels of racism exhibited by patients and colleagues (Sprinks 2008) can be contrasted with the positive contribution that black nurses have made to the NHS (Kramer 2006). Trade unions such as Unison have responded with programmes of action to support complainants of racism in the NHS, and encourage staff to confront racism in the workplace (Unison 2007, 2008). 
Epidemiological statistics and hospital admission rates show that ethnic minorities are diagnosed with serious mental illness at a rate disproportionate to their numbers in the UK population (see Health Care Commission, Mental Health Act Commission \& National Institute for Mental Health England 2007, 2005, Bhui et al 2003, Cohrane \& Bal 1989, Glover 1989, Harrison et al 1988, Dean et al 1981, Cohrane 1977, Rwgellera 1977, Odergaard 1932). Black men are over-represented in all diagnostic categories of mental disorder except personality disorders (Mikton \& Grounds 2007, Minnis et al 2001, Stowell Smith \& McKeown 1999), most notably attracting diagnoses of psychosis or schizophrenia. Literature mainly focuses on the experiences of African and Afro-Caribbean men, however, similar anomalies have been noted in relation to other ethnic groups (Audini \& Lelliott 2002) including people of Irish heritage (Clarke 1998).

Black men in particular are typically under-represented in primary care but are increasingly concentrated at the hard end of services, with rates of over-representation most obvious in high secure services (Boast \& Chesterman 1995, Jones \& Berry 1986). Mental health legislation, the police and courts are more likely to be involved in admission to care (Morgan et al 2004, Barnes et al 1990, Browne 1990, Moodley \& Thornicroft 1988, Rogers \& Faulkner 1987, McGovern \& Cope 1987). Once in services, physical treatments rather than psychotherapies are more likely to be administered. This includes greater use of medication, injections, ECT, physical restraint and seclusion than for white counterparts (Mason 1995) and, in the extreme, a greater incidence of death following attempts to administer intra-muscular medication simultaneously with physical restraint (see Blofeld 2003, McKeown \& Stowell Smith 2001, Prins 1993). It has been noted that staff can assume black patients to pose an increased risk of violence in the absence of objective evidence (see Lawson, Jerome \& Werner 1984, Moodley \& Thornicroft 1988, Noble \& Rodger 1989), possibly associated with a 'big, black and dangerous' stereotype (Prins 1993, Francis 1989). Official inquiries into serious failings in psychiatric care have pointed to evidence of racism on the part of both staff and patients (Blofeld 2003, Committee of Inquiry 1992). 
Efforts at explanation have usually focused on the over-representation in diagnosis of mental illness as a point of departure. Different theories that have emerged are either conservative, making little criticism of psychiatric care, or more radical in suggesting that transformations of care are needed. From one perspective, the greater incidence of mental disorder is real, with black people identified as having increased vulnerability. This is typically explained in terms of innate biology, the adverse influence of social disadvantage and racism, or interplay between the two. Alternately, discrepancies in diagnosis are attributed to ethnocentric bias and lack of cultural sensitivity in the system. The latter perspective has supported the development of alternative black mental health services and transcultural psychiatry movement (Littlewood 1990).

Social constructionist critics, similarly, recognise the role of racial stereotypes but conceive of these, and their effects, in a slightly different way (see Parker et al 1995). Such commentators discredit the terminology of 'race', concerning themselves with the role of discourse in shaping how people make sense of such powerful social categories (Rustin 1992). In these accounts an idealised white, western self-hood (see Geertz 1979) is contrasted with a denigrated black 'otherness', operating in the historical oppression of black people and serving the interests of powerful groups. It is taken for granted that the archetypal white self, defined in terms of individuality, intellect, and capacity for emotion, is the natural subject of standard psychiatric practice and psychotherapy. Conversely, black self-hood is alienated and dehumanised, depicted in terms of exaggerated physicality and sexuality (see Miles 1989, Dalal 1993, Stowell-Smith \& McKeown 2001) as a repository for unwanted aspects of the selves of the dominant group. The specific correspondence of black otherness with physicality is a short step from the pernicious 'big, black and dangerous' representation noted previously (Mckeown et al 2008). Those working in the field of masculinity (e.g. Connell 1995, 2005; Segal 1997) have noted how social constructions of a subordinated black masculinity generate public fears and locate a sense of threat. 
The seeming paradox of over-diagnosis in all categories other than personality disorder can be explained, in part at least, with reference to the discourses described above. If black selves are thought of in ways that emphasise physicality over psyche, then it might prove challenging in the least to include them in categories defined in terms of disorder of mind, but much easier to apply the nosology of schizophrenia, essentially defined by psychiatry as a physical illness of brain biochemistry. This reasoning, unconscious or not, invites the disproportionate application of physical rather than psychological treatments (Stowell-Smith \& McKeown 1999). Mikton and Grounds (2007) using a case-vignette approach confirmed that certain categories of personality disorder are underdiagnosed and offer a number of possible explanations for this. These include the existence of a prevailing negative stereotype of black criminality as 'normal' and hence not pathological, a lack of cultural sensitivity in the assessment process and, interestingly, a possibility that psychiatrists are sensitive to the potential accusation of racial bias in the allocation of a diagnostic label with stigmatising and pejorative connotations. Whichever of these attempts at understanding are most accurate or plausible, clearly the intersection of race and psychiatry is a complex and problematic area.

Though the treatment of race is key, it is not the only signifier of problems in psychiatry's historical engagement with constructs of human difference. Psychiatric care has faced similar critique in its treatment of women, the notion of gender, and differences in sexuality. Intellectuals and activists have drawn attention to patriarchal inequalities in women's historical engagement with the institutions of mental health (Parry-Crooke 2001, Williams et al 2001, Pilgrim \& Rogers 1999, Busfield, 1996, Allen 1986, Chesler 1972), abuse in therapy (Masson 1988) and calls for feminist inspired therapies (Liebling \& Chipchase 2000, Burstow 1992, Worell and Remer 1992). A number of relatively recent policy statements have been formulated to address key issues in the mental health care of women (DH 2003, NHSE 1999). The first edition of the American Psychiatric Association Diagnostic and Statistical Manual (DSM-1) classified homosexuality as a mental disorder and, until relatively recent times, has deployed 'treatments' via psychotherapy, electric-shock (ECT), 
medication, or invasive and mutilating surgery (LeVay 1997). The eugenics movement ignobly initiated programmes of sterilisation of the mentally ill and learning disabled (Cogdell 2006), and it is worth remembering that in the early decades of the $20^{\text {th }}$ century such ideas and practices were a significant element of the scientific mainstream, influential in medicine, psychiatry and government. There is evidence that certain sterilisation programmes and dubiously unethical and racialised research programmes were undertaken in modern western nations up to the 1970 s (Grekul et al 2004, Dowbiggin 2003). In a self-published monograph, Wolfensberger (1987) argued that there has been a much larger project of legitimated 'deathmaking' for devalued and disabled people in society, constituting a 'new genocide'; health and social care services, often, subtly involved in complex processes that indirectly hasten people's deaths. Life-limiting effects of psychiatric medication and its association with increased vulnerability to accidental death, or the adverse impact on health of social marginalisation are cited as examples of this.

A significant and unwholesome element of academic psychology has been the various attempts to 'scientifically' assert the superiority of white races over black. This body of work, notably associated with Charles Murray in the US, Jean Philippe Rushton in Canada, and Richard Lynn in the UK typically and controversially claims genetic differences in intelligence between races (see Rushton 1997, Lynn 1997, Herrnstein \& Murray 1994). These usually focus on studies of IQ, but occasionally include a bizarre interest in cranial measurement, sexual activity and penis size (Lieberman 2001, Younge 1999). Authors such as Rushton have been guilty of inadequate scholarly methods and dubious associations with right-wing pressure groups and funding sources, yet they retain the protection of academic posts. Their numerous publications furnish fascist politicians with spurious ammunition for their racist arguments. Theories and views about race and human difference are not merely abstract or neutral in their effects; they can and are put to use in the service of political extremism, discrimination and abuse. This has been true across history with, for example, representations of black otherness underpinning colonialism and the slave trade. 


\section{Fascism and the abuse of vulnerable and mentally ill people}

In modern times this conjunction of theory and practice reached its most acknowledged apotheosis in the particular Nazi doctrine of racial superiority and inferiority linked to goals of national racial purity. Commitment to, and criminal convictions for, Holocaust denial characterises the political and pseudo-intellectual leadership of the BNP (Taylor 2000, Lipstadt 1993), and firmly locates their allegiance to a despotic party responsible for the systematic extermination of millions of European Jews, and others, in the years between 1939 and 1945. Commenting on the bureaucratisation of mass murder in Nazi Germany, Friedlander (1997) charts the emergence of an elaborate and repressive legal-medical system that underpinned the machinery of racial genocide. Eugenic science and ideology merged in the quest to cleanse the social body, and 'blood' of the Third Reich, of groups deemed to be undesirable and inferior elements:

"Those judged to be suffering from hereditary diseases and handicaps had to be purged from the national gene pool in the same way that those considered aliens - Jews, Gypsies, Blacks - had to be excluded from the national community" (Friedlander 1997: 90).

For Seeman (2005: 224), recently discovered information from the Berlin archives provide more than a shameful record of state sanctioned murder, in permitting an opportunity for contemporary introspection about collusive relations between medicine and political ideology:

"The Nazi era has taught us that medical values are malleable and can all too easily be shaped by priorities of the state, personal agendas, careerism, the profit motive, and deep biases in society and ourselves".

Physicians and academics, it is noted, were early recruits to National Socialism, where a tradition of preventive public health took precedence over individual welfare and prioritised the well-being of the nation state (Volksgesundheit). Though German psychology had led to pioneering intellectual 
advances in the mid to late nineteenth century, it was psychiatrists who would be most actively involved in the forced sterilization and gassing of adults and children with a mental handicap, mental illness, or other form of disability. Shortly after being appointed Reich Chancellor in 1933, Hitler initiated, and enacted, the Law for the Prevention of Progeny of Hereditary Disease. Hassenfeld (2002) reports how this legislation was authored by an eminent psychiatrist, and researcher into the genetics of schizophrenia, Dr Ernst Reudin. Similarly, psychiatric expertise directed operations of the Section for Research on Race Hygiene and Population Biology of the German National Department of Health, established in 1936, and the 220 regional 'genetic health courts' aimed at preventing the reproduction of those identified as genetically or racially inferior. Each of these comprised of a judge and two doctors:

"The physician members of the court took as few as ten minutes to pass sentence on patients in proceedings from which the public was barred. The patients selected for compulsory sterilization were ordered to appear at a particular clinic, and if they failed to appear of their own accord, they were brought to the operating table by the police... 300,000 to 400,000 persons were forcibly sterilized and 5000 women died as a result of the surgery" (Hassenfeld 2002: 185).

The Law Against Dangerous Habitual Criminals (1935) blurred, further, the boundaries between antisocial behaviour and criminality, providing for indeterminate detention of law-breakers and compulsory castration of sexual offenders. The combination of social Darwinism, forced prevention of disability, political propaganda, and rising financial cost of the Nazi war machine was instrumental in the move toward euthanasia in psychiatric hospitals, and later the mass exterminations of the death camps (Michalsen \& Reinhart 2006, Mostert 2002). Though medical killing was authorised by Führer decree, without legal discussion or sanction (Seeman 2005), physicians and nurses were, overwhelmingly, active participants in the macabre process of murdering their patients (Benedict et al 2007, Benedict \& Kuhla 1999, Lagerwey 1999, Steppe 1992). 'Killing centres' were established at working asylums to eradicate individuals described in terms 'ballast lives' (ballastexistenzen), 'useless eaters' (unnütze) and 'life unworthy of life' (lebensunwerten Lebens); deemed a sacrifice of 
those who consumed valuable resources without any economic contribution or social value (Thomas et al 2006, Mostert 2002):

"Official notions of difference, which would later find their most diabolical expression in the murder of the Jews, were first expressed in state-sanctioned killings of children and adults with a wide range of physical, emotional, and intellectual disabilities" (Mostert 2002: 157).

The organised euthanasia of 7000 adults, conducted under the auspices of 'Aktion T4', ceased in 1941 as a result of public and church protest. It was replaced, though, by what is generally referred to as a 'wild euthanasia' programme, undertaken under 'special orders' in selected psychiatric centres such as Meseritz-Obrawalde state hospital (Benedict et al 2007). The latter author's remark that, here, doctors would select patients to die, but nurses and caregivers conducted the actual killing, often described as 'medical therapy'; individual ethics abandoned for the 'greater good' of the Government:

"Some of the nurses put their moral duty to obey orders ahead of their moral duty not to kill. Others believed that what they did was not killing but merely the outcome of obeying a morally licit command" (Benedict et al 2007: 791).

Steppe (1992) refers to the nurse, during the Nazi period, as the 'political soldier' of the German health service. If ethical frameworks and value systems remained almost intact, professional consciousness became subsumed within the discourse of a dominant political ideology. Execution or internment in concentration camps faced those nurses who resisted participation, but this, alone, does not account for the larger number who assumed a pivotal role in the murders. It is suggested that as the profession became increasingly politicised and surrendered to state control, under the Reich's Union of German Nurses and Nursing Assistants, individual nurses were compelled to make ethical choices outwith any professional support (Lagerwey 1999). Beyond ideological commitment, other commentators reflect on factors that compounded nursing involvement in genocidal killing (Benedict et al 2007, Ost 2006, Benedict \& Kuhla 1999). These include deference to male/medical 
authority in a hierarchical hospital system, the role of religion in poor quality nurse education, and duress coupled with a belief that their actions relieved patient suffering. Nor, in a depressed economy, can financial incentives be discounted. In addition to job security in a depressed economy, midwives, for instance received a monetary bonus for each disabled child that they reported to the Reich Ministry (Mostert 2002). Notwithstanding analytic frameworks to explain the actions of nurses during this period and the abuse of terminology about 'mercy killing', where there was no mercy (Michalsen \& Reinhart 2006), raise profound and troubling questions for contemporary practice in the context of an increasing right-wing political presence. As Benedict and Kuhla (1999: 261) remind us:

\footnotetext{
“The history of the nurses' participation presents today's nurses with the obligations of being sensitive to any indications of discrimination toward any individuals or groups of people and never letting professional behaviour become secondary to individual morality".
}

\section{Positioning ethics and anti-discrimination in healthcare practice}

One of the foundational figures of British mental health nursing, Annie Altschul, emphasised the centrality of a relational approach to caring for people with mental health problems. A survivor of Nazi persecution, who faced a rising tide of anti-Semitism, she fled Austria on Hitler's assumption to power (Nolan 1999). Altschul had firsthand experience of being treated as an 'alien' in wartime Britain. On becoming a trainee nurse she witnessed discriminatory practices towards Gypsies that precipitated a lifelong commitment to the marginalised (Nolan 2001). Altschul shared a commitment to socialist and humanist philosophies with other significant European commentators on mental health who also fled the Nazi regime, including, notably, Herbert Marcuse, Erich Fromm and Wilhelm Reich. These authors developed theories of human relations beyond a narrow notion of the individual towards a much more collective and social view; a standpoint representing the antithesis of the dehumanised and denigrated 'otherness' which informs the rhetoric and ideology of fascism. 
Easlea (1981) remarks on the brutality and hardness of the political messages communicated in the European fascist-Nazi revolutions of the 1920s and 30s. For the Nazis, the idea of the master race was bound up with a particular representation of virility and manhood linked to violence and sadism. Reich (1946), Marcuse (1964), and Fromm (1973) and reflecting on Hegel's notion of the 'slaughter bench of history' ultimately reach optimistic conclusions regarding 'human nature'. The propensity for sadistic expressions of human conflict attributed, variously, to material scarcity, sexual repression and deference to authoritarianism; factors which coalesced with tragic results in Nazi Germany. The solution is a more egalitarian transformation of society.

Drawing on literary texts published by Holocaust survivors, highlighting the dehumanising effects of victimhood and the complicity of certain health practitioners, including nurses, in the Nazi victimisation, McKie (2004) derives some pertinent conclusions relevant to contemporary nursing practice. In particular, these emphasise ethical concepts of witness and virtues. These themes, developed to make a case for a professional ethics of nursing, are grounded in recognition of past failings of ethics and humanity and encompass the idea of a moral community of nursing. This includes the need to apply lessons from the Holocaust to current and future practice. The thesis begins with Primo Levi's account of the moral degradation of the concentration camp inmate, where 'the demolition of a man' involved stripping him of belongings, clothing, hair, and name; not listened to, not understood, the strength had to be found to keep hold, despite all this, of one's sense of being a person. It is concluded:

\footnotetext{
"It behoves nurses to listen, to understand, to restore dignity and to place personhood at the very centre of their practice now and in the future" (McKie 2004: 147).
}

This 'ethics of testimony' is central to the work of Jane Georges (2004) who, writing from a critical feminist perspective, has explored the role of nurses in the death camps of the Third Reich, and Auschwitz in particular (2006). Here, a political reconceptualisation of 'suffering' has vital relevance in the discourse of nursing philosophy and science. Within this analysis, self-reflection assumes a 
prominent position in challenging a history of Eurocentric, reductionist, accounts that distance us from the suffering of others, whether past or present. Attention to structural inequalities such as sexism, racism and militarism, replace dominant cultural narratives that see individual 'pathology' as an explanation and 'therapy' as an answer. Keenly avoiding the risk of privileging one particular set of survivor stories, events in the Nazi period offer distinct insights for professional illumination:

"The narratives that emerge from this clearly documented evidence of active involvement of professional nurses in mass murder, torture, and unethical experimentation are uniformly chilling and extremely significant for consideration for contemporary nursing" (Georges 2006: 161).

Evidence of the resocialisation of nursing within National Socialist ideology, and complicity of individual nurses in genocidal extermination, is increasingly well documented and accessible (Burleigh 2002). However, the involvement of 'prisoner nurses' detained in Nazi concentration camps clearly reframes ethical theorising about 'choice' and situates personal decision-making in the context of politics and power relations. The archival testimony of women who underwent horrific sterilization experiments in Auschwitz reveal the part played by fellow prisoners with a nursing qualification (Georges 2006). It is suggested that masculinist discourses of 'disconnection' constructed a bio-political space where moral categories collapsed and sexualised violence was inscribed on the body of the 'other'. Knowledge of suffering, rather than history, is pivotal to BenSefer's (2006) discussion of an Australian nursing educational initiative aimed at combating racism, hatred and intolerance. Holocaust studies, contextualised within the curricula, provided a mode of experiential learning in facilitating undergraduate debate about ethical challenges. In particular, the disconcerting mixture of killing and caring is identified as worthy of consideration in relation to contemporary nursing practice:

"This led some students to raise the question of what is a caring practice and whether or not some of the nursing activities performed in the overall goal of helping the patient could be construed as 'torturing' them at some level, while as nurses, they were convinced that they were helping. The 
question made a number of students uncomfortable as they reflected back over their own clinical experiences and what they might have done inadvertently" (Ben-Sefer 2006: 37).

\section{Conclusions}

Right-wing British Nationalism is inextricably linked to historical strands of fascist ideology including its apotheosis in Hitler's Nazism. The BNP is spiritually at home with violent racism. Many of its leaders and members have convictions for thuggery, and share a predilection for dressing up in Nazi regalia. As such, their recent attempts to present a more sober image in public are a thin veneer laid over policies and attitudes that are totally at odds with the core professional values of nursing. If the NMC Code prohibits nurses discriminating against people under their care, it follows that belonging to a party propagating discriminatory ideology ought to be incompatible with membership of the nursing community. Within western liberal democracies this raises a significant moral dilemma: the professional code offers a prescription against discriminatory ideas and practices yet freedoms of choice and speech represent valued elements of democratic citizenship. We contend that the implications of the historical and theoretical material covered in this article make the case that the social implications of failing to resist fascist nationalism, within society as a whole and nursing and healthcare work in particular, are so grave that we have to recognise the limits of regarding all rights and freedoms as having equal value in all circumstances. This is a case where freedom of choice to join any political party, or the freedom of speech to espouse any political doctrine does not supersede the rights of people not to be discriminated against or abused. For these reasons we would support the recent decision taken at Unison's Health Conference to seek statutory powers to bar BNP members from nursing (Nursingtimes.net 2009). 
The historical record shows that timidity in standing up to fascism only allows it to flourish and it is the fascists who pose the real threat to our democratic rights and freedoms. One way to affirm the requirements of the regulatory body would be for mental health nurses to connect with progressive strands of nursing history, revisiting Altschul's attachment to the underdog, and be actively engaged in the vanguard of resistance to racism, discrimination and fascism. In doing so, individual nurses and their collective organisations can creatively connect with other organisations of resistance, including anti-racist community groups and the service user movement. Such alliances afford the opportunity to open up a dialogue that moves us towards the realisation of a new politics of mental health that has no room for racism and discrimination, celebrating the creativity and vitality of difference but always affirming common humanity.

A version of this paper was presented at the Fourteenth Alternative Futures and Popular Protest Conference Manchester, $15^{\text {th }}-17^{\text {th }}$ April, 2009 


\section{References}

Allen, H. (1986) Psychiatry and the construction of the feminine. In Miller P., Rose, N. (eds) The power of psychiatry. Polity Press, Cambridge. pp 85-111.

Audini, B., Lelliott, P. (2002) Age, gender and ethnicity of those detained under Part II of the Mental Health Act 1983. British Journal of Psychiatry, 180: 222-226.

Barnes, M., Bowl, R., Fisher, M. (1990) Sectioned: Social services and the 1983 Mental Health Act. London, Tavistock.

Baxter, D. (2009) Fallacies of Integration.

www.bnp.org.uk/organisers/store/ideology/fallacies of integration.pdf accessed February 112009

Benedict, S., Caplan, A., Lafrenz Page, T. (2007) Duty and 'euthanasia': The nurses of MeseritzObrawalde. Nursing Ethics, 14 (6): 781-794.

Benedict, S., Kuhla, J. (1999) Nurses' participation in the euthanasia programs of Nazi Germany. Western Journal of Nursing Research, 21 (2): 246-263.

Ben-Sefer, E. (2006) Lessons from the past for contemporary Australian nursing students: The Nazi euthanasia program. Nurse Education in Practice, 6: 31-39.

Bhui, K., Stansfeld, S. A., Holt, S., Priebe, S., Mole, F., Feder, G. (2003) Ethnic variations in the pathways to and use of specialist mental health services. British Journal of Psychiatry, 182: 105-116. Blofeld, J. (2003) Independent inquiry into the death of David Bennett report. Norwich, Norfolk, Suffolk and Cambridge Strategic Health Authority.

BNP (2009) British National Party website. http://bnp.org.uk/ accessed February 112009.

Boast, N., Chesterman, P. (1995) Black people and secure psychiatric facilities: Patterns of processing and the role of stereotypes. British Journal of Criminology, 35: 218-35. 
Brěchon, P., Mitra, S.K. The National Front in France: The emergence of an extreme right protest movement. Comparative Politics, 25 (1): 63-82.

Browne, D. (1990) Black people, mental health and the courts. London, NACRO.

Burleigh, M. (2002) Death and deliverance: Euthanasia in Germany, 1900-1945. Pan Macmillan, London.

Burstow, B. (1992) Radical feminist therapy. Newbury Park, Sage.

Busfield, J. (1996) Men, Women and Madness: Understanding gender and mental disorder. London, Macmillan.

Chesler, P. (1972) Women and madness. Allen Lane, London.

Clarke, L. (1998) Mental illness and Irish people: Stereotypes, determinants and changing perspectives. Journal of Psychiatric \& Mental Health Nursing, 5: 309-316.

Cohrane, R. (1977) Mental illness in immigrants in England and Wales: An analysis of mental hospital admissions, 1971. Social Psychiatry, 12: 25-35.

Cochrane, R., Bal, S. (1989) Mental hospital admission rates of immigrants to England: A comparison of 1971 and 1981. Social Psychiatry and Psychiatric Epidemiology, 24: 2-11.

Cogdell, C (2006). Popular eugenics: National efficiency and American mass culture in the 1930s. Athens, $\mathrm{OH}$, Ohio University Press.

Committee of Inquiry (1992) Report of the Committee of Inquiry into Complaints about Ashworth Hospital. London, HMSO.

Connell, R.W. (1995) Masculinities. Cambridge, Polity Press 
Connell, R.W. (2005) Masculinities, $2^{\text {nd }}$ ed. Cambridge, Polity Press

Dalal, F.N. (1993) 'Race' and racism: An attempt to organise difference. Group Analysis, 26: 277-90.

Dean, G., Walsh, D., Downing, H., Shelley, E. (1981) First admissions of native-born immigrants to psychiatric hospitals in South East England, 1976. British Journal of Psychiatry, 139: 506-12.

Department of Health (2005) Delivering race equality in mental health care and the government's response to the independent inquiry into the death of David Bennett. London, $\mathrm{DH}$.

Department of Health (2003) Mainstreaming gender and women's mental health: Implementation guidance. London, $\mathrm{DH}$.

Dowbiggin, I. (2003) Keeping America sane: Psychiatry and eugenics in the United States and Canada 1880-1940. Ithica, Cornell University Press.

Easlea, B. (1981) Science and sexual oppression: Patriarchy's confrontation with woman and nature. Weidenfield and Nicholson, London.

Francis, E. (1989) Black people, dangerousness and psychiatric compulsion. In Brackx, A., Grimshaw, C. (eds) Mental health care in crisis. London, Pluto.

Friedlander H. (1997) Registering the handicapped in Nazi Germany: A case study. Jewish History, 11 (2): 89-98.

Fromm, E. (1973) The anatomy of human destructiveness. Holt, Rinehart \& Winston, Austin, Texas.

Geertz, C. (1979) From the natives point of view: On the nature of anthropological understanding. In Rabinow, P., Sullivan, W. (eds) Interpretive Social Science. Berkeley, University of California Press.

Georges, J. M. (2004) The politics of suffering: Implications for nursing science. Advances in Nursing Science, 27 (4): 250-256. 
Georges, J.M. (2006) An ethics of testimony: Prisoner nurses at Auschwitz. Advances in Nursing Science, 29 (2): 161-169.

Glover, G. (1989) Why is there a high rate of schizophrenia in British Caribbean's? British Journal of Hospital Medicine, 42: 48-51.

Grekul, J., Krahn, H., Odynak, D. (2004) 'Sterilizing the feeble-minded': Eugenics in Alberta, Canada, 1929-1972. Journal of Historical Sociology, 17 (4): 358-384.

Harrison, G., Owens, D., Holton, A., Nielson, D., Boot, D. (1988) A prospective study of severe mental disorder in Afro-Caribbean patients. Psychological Medicine, 18: 643-57.

Hassenfeld, I.N. (2002) Doctor-patient relations in Nazi Germany and the fate of psychiatric patients. Psychiatric Quarterly, 73 (3): 183-194.

Healthcare Commission, Mental Health Act Commission, National Institute for Mental Health in England (2005). Count me in: Results of a national census of inpatients in mental health hospitals and facilities in England and Wales. London, Healthcare Commission.

Healthcare Commission, Care Services Improvement Partnership, National Institute for Mental Health in England (2007). Count me in: Results of the 2006 national census of inpatients in mental health and learning disability services in England and Wales. London, Healthcare Commission.

Herrnstein, R., Murray, C. (1994) The bell-curve: Intelligence and class structure in American life. New York, Free Press.

Husbands, C.T. (1988) Extreme right-wing politics in Great Britain: The recent marginalisation of The National Front. West European Politics, 11: 65-79.

Jones, G., Berry, M. (1986) Regional secure units: The emerging picture. In Edwards, G. (ed) Current Issues in Clinical Psychology, Volume 4. London, Plenum. pp 111-19. 
Keating, F., Robertson, D., McCulloch, A., Francis, E. (2002). Breaking the circles of fear: A review of the relationship between mental health services and African and Caribbean communities. London, Sainsbury Centre for Mental Health.

Kramer, A. (2006) Many rivers to cross: The history of the Caribbean contribution to the NHS. Sugar Media/The Stationary Office, London.

Lagerwey, M.D. (1999) Nursing ethics at Hadamar. Qualitative Health Research, 9 (6): 759-772.

Lawson, W., Jerome, A., Werner, P. (1984) Race, violence and psychopathology. The Journal of Clinical Psychiatry, 45: 294-97.

LeVay, S. (1997) Queer Science: The use and abuse of research into homosexuality. MIT Press, Cambridge MA.

Lieberman, L. (2001) How 'caucasoids' got such big crania and why they shrank. Current Anthropology, 42 (1): 69-95.

Liebling, H., Chipchase, H. (2000) Women who self-harm in a high security hospital. In Mercer, D., Mason, T., McKeown, M., McCann, G. (eds) Forensic Mental Health Care: A case study approach. Edingburgh, Churchill Livingstone. pp. 101-109.

Lipstadt, D. (1993) Denying the Holocaust: The growing assault on truth and memory. London, Penguin .

Littlewood, R. (1990) From categories to contexts: A decade of the new cross-cultural psychiatry. British Journal of Psychiatry, 156: 308-27.

Luther, K.R. (2000) Austria: A democracy under threat from the Freedom Party. Parliamentary Affairs, 53: 426-442 
Lynn, R. (1997) Geographical variation in intelligence. In The scientific study of human nature: esays in honour of H. J. Eysenck. New York, Pergamon Press.

MacPherson, W. (1999) The Stephen Lawrence Inquiry: Report of an inquiry by Sir William MacPherson of Cluny. Cm 4262-I. The Stationary Office, London.

Marcuse, H. (1964) One dimensional man. Routledge, London.

Mason, T. (1995) Seclusion in the special hospitals: A descriptive and analytic analysis. London, Special Hospitals Service Authority.

Masson, J. (1988) Against Therapy. London, Harper Collins.

McGovern, D., Cope, R. (1987) The compulsory detention of males of different ethnic groups. British Journal of Psychiatry, 150: 505-12.

McKeown, M., Mercer, D. (2008) BNP and nursing ideologies are incompatible. Nursing Times, 104 (50/51): 16 .

McKeown, M., Robertson, S., Habte-Mariam, Z., Stowell Smith, M. (2008) Masculinity and emasculation for black men in modern mental health care. Ethnicity and Inequalities in Health and Social Care, 1 (1): 42-51.

McKie, A. (2004) 'The demolition of a man': Lessons from the holocaust literature for the teaching of nursing ethics. Nursing Ethics, 11 (2): 138-149.

Michalsen, A., Reinhart, K. (2006) 'Euthanasia': A confusing term, abused under the Nazi regime and misused in present end-of-life debate. Intensive Care Medicine, 32: 1304-1310.

Mikton, C., Grounds, A. (2007) Cross-cultural clinical judgement bias in personality disorder diagnosis by forensic psychiatrists in the UK: A case-vignette study. Journal of Personality Disorders, 21 (4): 400-417. 
Minnis, H., McMillan, A., Gillies, M., Smith, S. (2001) Racial stereotyping: Survey of psychiatrists in the United Kingdom. British Medical Journal, 323: 905-906.

Moodley, P., Thorneycroft, G. (1988) Ethnic Group and Compulsory Detention. Medicine, Science and the Law, 28: 324-28.

Morgan, C., Mallett, R., Hutchinson, G., Leff, J. (2004) Negative pathways to psychiatric care and ethnicity: The bridge between social science and psychiatry. Social Science \& Medicine, 58: 739-752. Mostert, M.P. (2002) Useless eaters: Disability as genocidal marker in Nazi Germany. The Journal of Special Education, 36 (3): 157-170.

National Health Service Executive (1999) Safety, privacy and dignity in mental health units. London, Department of Health.

National Institute for Mental Health England (2003) Inside outside: Improving mental health services for black and minority communities in England. London, DH.

Newman, M. (2009) Petition calls for sacking of lecturer named on leaked BNP members' list. Times Higher Education, 12-18 ${ }^{\text {th }}$ March, 1,887: 11.

NMC (2008) The code: Standards of conduct, performance and ethics for nurses and midwives. London, Nursing and Midwifery Council.

Noble, P., Rodger, S. (1989) Violence by psychiatric in-patients. British Journal of Psychiatry, 155: 384-90.

Nolan, P. (1999) Annie Altschul's legacy to $20^{\text {th }}$ century British mental health nursing. Journal of Psychiatric and Mental Health Nursing, 6: 267-272.

Nolan P. 'Returning to Whence I Came' based on conversations with Annie Altschul. In 'A Festschrift for Annie Altschul', 2001: Online UKCHN. Available at: http://www.ukchnm.org/ accessed February 232009 
Nursing and Midwifery Council (2009) website. Advice on political affiliations. http://www.nmcuk.org/aArticle.aspx?ArticleID=3429\&Keyword=BNP. Accessed February 62009.

Nursingtimes.net (2009) Calls to ban 'nasty, racist' BNP members from nursing.

http://www.nursingtimes.net/whats-new-in-nursing/unison/calls-to-ban-nasty-racist-bnp-members-from-

nursing/5000675.article accessed April 242009.

Odergaard, O. (1932) Emigration and insanity. Acta Psychiatrica Neurologica Scandaniaca, Suppl. 4. 1206

Ost, S. (2006) Doctors and nurses of death: A case study of eugenically motivated killing under the Nazi 'euthanasia' programme. Liverpool Law Review, 27: 5-30.

Parker, I. (2001) Psychology Politics Resistance: Asylum in the $21^{\text {st }}$ century. Asylum Magazine, 13, 1, 14 15.

Parker, I., Georgaca, E., Harper, D., McClaughlin, T., Stowell Smith, M. (1995) Deconstructing psychopathology. London, Sage.

Parry-Crooke, G. (2001) An evaluation of working with women with mental health needs. University of North London, London.

Prins, H. (1993) Report of the committee of inquiry into the death in Broadmoor Hospital of Orville Blackwood and a review of the death of two other Afro-Caribbean patients: Big, black and dangerous? London, Special Hospitals Service Authority.

Psychologists against the Nazis (2001). Anti Nazi League. Psychologists against the Nazis (pamphlet) found at www.discourseunit.com.ppr.pan

Rattansi, A. (2007) Racism: A very short introduction. Oxford, Oxford University Press.

Reich, W. (1946) Mass psychology of fascism. Trans. Wolfe T. P. Orgone Institute Press, New York. 
Rogers, A., Faulkner, A. (1987) A Place of Safety: MINDs research into police referrals to the psychiatric services. London, MIND.

Rogers, A. Pilgrim D., (2005) A sociology of mental health and illness, third edition. Buckingham, Open University Press.

Rushton, J. P. (1997) Race, evolution and behaviour: A life history perspective. New Brunswick, Transaction Publishers.

Rustin, M. (1992) The good society and the inner world. London, Verso.

Rwgellera, G. (1977) Psychiatric morbidity among West Africans and West Indians living in London. Psychological Medicine, 7: 317-29.

Seeman, M.V. (2005) Psychiatry in the Nazi era. Canadian Journal of Psychiatry, 50 (4): 218-224.

Segal L. (1997) Slow motion: Changing masculinities, changing men, 2nd Ed. London, Virago Press. Sprinks, J. 92008) Diversity champions needed to tackle racism against staff. Nursing Standard, 23 (4): 12

Steppe H. (1992) Nursing in Nazi Germany. Western Journal of Nursing Research, 14 (6): 744-753.

Stowell-Smith, M., McKeown, M. (1999) Race, psychopathy and self: A discourse analytic study. British Journal of Medical Psychology, 72: 459-470.

Stowell-Smith, M. \& McKeown, M. (2001) Race, stigma and stereotyping: The construction of difference in forensic care. In Carlisle, C., Mason, M., Watkins, C. [eds] Stigma and Social Exclusion in Health. Routledge, London.

Taylor, K. (2000) Holocaust denial: The David Irving trial and international revisionism. London, Searchlight. 
Thomas, F.P., Beres, A., Shevell, M.I. (2006) 'A cold wind coming': Heinrich Gross and child euthanasia in Vienna. Journal of Child Neurology, 1: 342-348.

Unison (2007) See racism, hear racism, report racism. Unison, London.

Unison (2008) Challenge racism in the workplace. Unison, London.

Unison Communications (2008) Poster: Public Health Warning: The BNP Can Seriously Damage Your Public Services. Unison Communications Unit, Mabledon Place, London: CU/March 2008/17198/2663/UNP ref 9859.

Ware, V. (1996) Island racism: Gender place and white power. Feminist Review, 54: 65-86.

Williams, J., Scott, S., Waterhouse, S. (2001) Mental health services for 'difficult' women: Reflections on some recent developments. Feminist Review, 68: 89-104.

Wofensberger, W. (1987) The new genocide of handicapped and afflicted people. Syracuse NY, author.

Worell, J., Remer, P. (1992) Feminist perspectives in therapy: An empowerment model for women. London, Wiley.

Younge, G. (1999, May 1) The gene genies. The Guardian 2, 2-3 
